\title{
A POLÍTICA NO FIM DA IDADE MÉDIA E SUA INFLUÊNCIA NO RENASCIMENTO: ENTRE O "DE REGNO - AD REGEM CYPRI", DE SÃO TOMÁS, E “IL PRINCIPE", DE MAQUIAVEL
}

José Arlindo de Aguiar Filho ${ }^{1}$

Universidade Estadual da Paraíba (UEPB)

(D) https://orcid.org/0000-0002-0363-9403

E-mail: arlindoaguiar@bol.com.br

\section{RESUMO:}

O presente artigo pretende esboçar um paralelo entre duas obras da filosofia política: o opúsculo inacabado "Do reino ou do governo dos príncipes ao Rei de Chipre" de São Tomás de Aquino, e o conhecido "O Príncipe" de Nicolau Maquiavel. O cotejo dos textos permite aproximações diretas entre dois momentos filosóficos distantes através da temática similar, pelo tratamento filosófico da tradição clássica, e pela sutileza do argumento que relaciona o bem comum com o privado, nas relações políticas. A análise divide-se em duas partes temáticas: a definição de governante, e, as características de seu ofício. Em Tomás, articula-se a influência da política aristotélica com o modo como a finalidade privada do governante se estabelece numa hierarquia dos fins, justificadora do governo e direcionada ao bem comum. Em Maquiavel se observa uma recepção diferente do pensamento antigo, ligado à retórica romana, e uma hierarquia própria dos fins, que se direciona, de modo semelhante ao tomasiano, para o bem comum, mas com um tratamento diferente quanto a como esse bem público se relaciona com o bem privado, tanto do governante, quanto do povo que lhe é sujeito. Desta comparação conclui-se por uma necessidade de estabelecer a complexidade da filosofia política na passagem da idade média para o renascimento que afaste a ideia de uma ruptura total, e permita entender como a idade moderna partilha, em continuidade, elementos medievais e os desenvolve muito mais do que os abandona.

PALAVRAS-CHAVE: São Tomás; Maquiavel; Política Renascentista; Bem comum.

\section{THE POLITICS AT THE END OF MIDDLE AGES AND ITS INFLUENCE ON RENAISSANCE: BETWEEN "REGNO - AD REGEM CYPRI", BY ST THOMAS, AND "IL PRINCIPE", BY MACHIAVELLI}

\begin{abstract}
:
The present article aims to sketch a parallel between two works of political philosophy: the unfinished pamphlet "From the Kingdom or Government of the Princes to the King of Cyprus" by St. Thomas Aquinas, and the wellknown "The Prince" by Niccolo Machiavelli. The collation of texts allows direct approximations between two distant philosophical moments through the similar theme, through the philosophical treatment of the classical tradition, and through the subtlety of the argument that relates the common good to the private, in the political relations. The analysis is divided into two thematic parts: the definition of ruler, and the characteristics of his craft. In Thomas, the influence of Aristotelian politics is articulated with the way in which the private purpose of the ruler is established in a hierarchy of ends that justifies the government and is directed to the common good. In Machiavelli there is a different reception of ancient thought, connected with Roman rhetoric, and a hierarchy of ends, which is directed, similarly to the Tomasian, for the common good, but with a different treatment as to how public good relates to the private good of both the ruler and the people subjected to him. From this comparison we conclude that there is a need to establish the complexity of political philosophy in the passage from the middle ages to the renaissance that removes the idea of a total rupture and allows us to understand how the modern age keep medieval elements and develops them much more than abandon them.
\end{abstract}

KEYWORDS: St Thomas; Machiavelli; Renaissance Politics; Common good.

${ }^{1}$ Doutor em Filosofia. Professor da Universidade Estadual da Paraíba (UEPB), Campina Grande - PB, Brasil.

FILHO, José Arlindo de Aguiar. A política no fim da idade média e sua influência no renascimento: entre o "De regno - ad regem cypri", de São Tomás, e "Il principe", de Maquiavel. Griot : Revista de Filosofia, Amargosa - BA, v.19, n.2, p.265-283, junho, 2019. 


\section{Introdução}

As obras clássicas da política possuem semelhanças entre si que revelam as continuidades da trajetória do pensamento, e, ao mesmo tempo, possuem também dessemelhanças, que permitem perceber as transformações da sociedade e da própria filosofia. A compreensão da história, com suas continuidades e descontinuidades, depende da linha traçada por esses clássicos. Aqui apresenta-se uma tentativa de traçar a linha entre o "De Regno - ad regem Cypri", de São Tomás de Aquino, e "Il Principe", de Nicolau Maquiavel.

O "De Regno" é um texto inacabado, escrito provavelmente por volta de 1265, composto de um primeiro livro completo, com dezesseis capítulos, e um segundo livro com dois capítulos apenas. Foi terminado posteriormente por Tolomeu de Lucca, um discípulo de Tomás, sendo o trecho acima apresentado a parte que se considera de autoria legítima². A obra pode ser lida como um "Espelho do Príncipe", um tipo de livro cuja intenção é mostrar um modelo perfeito de governante, formato muito comum na literatura política de então. Suas mais claras influências são o pensamento de Aristóteles e o de Santo Agostinho ${ }^{3}$, e não pode-se dizer que o texto é parte central da obra de Tomás. Também a sua recepção não é de relevância decisiva na historiografia do pensamento político, ao menos não como a do livro com o qual é comparada neste estudo.

O "Principe", foi escrito especificamente para um governante com o qual o autor pretendia angariar favores. Redigido em 1513, durante o exílio de Maquiavel em San Casciano, é uma obra acabada com vinte seis capítulos. Também pode ser entendido como um "Espelho do Príncipe"4, mas em sentido bastante diverso quanto ao modelo ideal de governante. Suas influências mais claras são o humanismo cívico do renascimento, com sua apropriação particular dos clássicos greco-romanos, e, a prática política na qual o autor esteve imerso durante os anos anteriores ao degredo. Ao contrário do "De Regno", o livro de Maquiavel só pode ser comparado ao Manifesto Comunista em termos de impacto na história das ideias políticas.

O paralelo que pretende-se traçar aqui parte da obra de São Tomás e através de suas especificidades busca em Maquiavel pontos de convergência e divergência conceitual. A trajetória percorrida por Tomás, ao ser posta lado a lado com o tratamento maquiavélico dos mesmos temas evidencia, além de continuidades

\footnotetext{
2 A edição utilizada é a tradução de Francisco Benjamim de Souza Neto, da coleção "Clássicos do pensamento político" da Vozes. O texto está apoiado na edição crítica leonina e na tradução anterior do professor Arlindo Veiga dos Santos e sua revisão pelo professor Carlos Arthur Ribeiro do Nascimento. É desta edição que foi seguida a divisão em capítulos e orientação quanto à extensão da autoria legítima de Tomás. (AQUINO, 1995 p.29,125)

${ }^{3}$ Discussão tratada em DE BONI (2004 p. 320).

4 Apesar de discordar desse posicionamento, a comparação de DE BONI é interessante por mostrar uma breve indicação comparativa que converge parcialmente com algumas conclusões deste artigo: "Alguns autores consideram Il príncipe de Maquiavel como sendo também um 'espelho do príncipe': embora não se possa concordar com tal afirmativa, não deixa de haver uma certa semelhança material entre tais obras (como a dedicatória, os títulos latinos dos capítulos e os exemplos tomados do passado). Mas a obra do pensador florentino é mais um 'antiespelho do principe' do que um 'espelho', um livro mais 'sociológico' do que 'ético', separando totalmente a política da ética. A Maquiavel interessa tão somente tratar dos meios para chegar ao poder e manter-se nele, sem se perguntar pela moralidade de tais meios e dos atos humanos em geral" (DE BONI, 2004 p. 316).
}

FILHO, José Arlindo de Aguiar. A política no fim da idade média e sua influência no renascimento: entre o "De regno - ad regem cypri", de São Tomás, e "Il principe", de Maquiavel. Griot : Revista de Filosofia, Amargosa - BA, v.19, n.2, p.265-283, junho, 2019. 
flagrantes e outras insuspeitas, esperadas descontinuidades reveladoras das transformações que duzentos anos de intervalo produziram no mundo político.

Após esse "mapeamento conceitual", o trabalho pretende analisar um ponto específico: o tratamento da relação entre bem comum e bem privado nas relações políticas. Essa temática surge no texto de Tomás de modo duplo e tem em Maquiavel uma ressonância enigmática, com fortes concordâncias quanto aos bens terrenos na hierarquia dos fins tomasiana e recusa sumária no tratamento dos bens divinos. A hipótese que se levanta como conclusão ao final da análise é a de que a leitura maquiavélica de Tomás reduz a complexidade da política medieval. $O$ pensamento renascentista no caso específico de Maquiavel, ao cortar a base sistemática e teológica de São Tomás permite o desenvolvimento de uma nova política. Livre da influência determinante da teologia, da sistematização metafísica, de débitos morais, e fundada na e para a prática empírica. Mas, o mais surpreendente, também encontramos essa política esboçada, sob o véu do cristianismo, em São Tomás! Maquiavel não precisaria construir muito, e sim demolir. Ao retirar o véu metafísico da política ele se torna um político moderno, sua façanha não foi criar um pensamento político a partir da falência do modelo medieval: foi desmascarar o modelo já subjacente no pensamento dos medievais e em vigor na prática dos Príncipes desde a antiguidade. Maquiavel é o personagem real que acusa: "o rei está nu".

A obra de Tomás possui uma clara divisão, indicada pelo próprio autor ${ }^{5}$, entre a definição do rei, nos capítulos 2 ao 12, e a caracterização do ofício de governar, nos capítulos 13 ao 16. A sistematização argumentativa bem ordenada deriva da definição as características do ofício, daí o destaque e maior tamanho dedicados à primeira parte. Já na obra de Maquiavel não encontramos a clareza da ordenação. Suas definições iniciais são brevíssimas e os comentários aos exemplos históricos são o lugar onde se revela indiretamente sua filosofia política. O texto possui dez capítulos a mais que o "De Regno" e podemos, como opção metodológica, dividi-lo com a mesma chave tomista: numa parte se ocupa de definir o Príncipe, noutra de prescrever seu ofício. Com esta visão podemos separar os capítulos 1 ao 12 como descrições historicamente fundamentadas do que são os principados e seus tipos mais importantes (e por derivação teremos a definição e os tipos de príncipes), e nos capítulos 13 ao 26 trata-se do ofício do Príncipe. Seguindo então a ordem, de Tomás para Maquiavel, comparemos os textos em duas partes observando a diferente definição e principalmente o diferente modo como é construída, para depois passarmos às prescrições para os governantes. Mas antes, há dois trechos excluídos da divisão que indicam a diferença de direção seguida pelos autores.

\section{Capítulo 1 de Tomás, Prólogo de Maquiavel}

\footnotetext{
${ }^{5} \mathrm{O}$ intervalo entre o início do livro e o capítulo 12 é concluído com a seguinte frase final: "O que é o rei, e que convém à multidão ter um rei, e, mais, que convém ao governante mostrar-se rei para a multidão subordinada, e não tirano, eis aí o que tínhamos de expor." (AQUINO, 1995 p. 158); em sequência o texto caminha até o final do capítulo 16 que assim conclui: "É, pois, isto o que compete ao ofício real, do que importa tratar detalhadamente com diligência." (AQUINO, 1995 p. 168). Daí para a frente o livro 2 apenas inicia a dar lições práticas de governo quando é deixado inacabado. O tratamento pragmático do detalhamento que seria dado ao ofício do príncipe leva a crer que a continuidade da obra a teria tornado muito mais similar ao "Príncipe" do que o é a partir da comparação com o texto disponível.
}

FILHO, José Arlindo de Aguiar. A política no fim da idade média e sua influência no renascimento: entre o "De regno - ad regem cypri", de São Tomás, e "Il principe", de Maquiavel. Griot : Revista de Filosofia, Amargosa - BA, v.19, n.2, p.265-283, junho, 2019. 
Para iniciar a comparação dos textos tomemos o primeiro capítulo de Tomás, no qual dedica o texto ao rei de Chipre. Nas breves linhas iniciais se revela o conteúdo previsto e seus fundamentos:

\begin{abstract}
Ao cogitar eu do que ofereceria digno da vossa excelência real e conveniente à minha profissão e ofício, ocorreu-me que, melhor havia de fazê-lo, escrevendo um livro sobre o governo régio, no qual expusesse acuradamente a origem do governo régio e quanto compete ao ofício de rei, segundo a autoridade da divina Escritura, os ensinamentos dos filósofos e o exemplo dos príncipes mais dignos de louvores[...]. (AQUINO, 1995 p.126)
\end{abstract}

A brevidade e objetividade desta introdução contrastam com o estilo indireto e retórico das recomendações feitas por Maquiavel a Lourenço de Medici no prólogo do "Principe".

\begin{abstract}
Costumam, as mais das vezes, os que desejam conquistar as boas graças de um príncipe fazer-se-lhe ao encontro com as coisas que entre os seus se tem por mais caras, ou com as quais o veem deleitar-se mais; daí o ver-se muitas vezes eles sererm presenteados com cavalos, armas, tecidos de ouro, pedras preciosas e ornamentos semelhantes, dignos da sua grandeza. Desejando, pois, eu oferecer-me a Vossa Magnificência com algum testemunho da minha servidão para com ela, não encontrei entre as minhas alfaias coisa que tenha por mais cara ou que estime tanto quanto o conhecimento das ações dos grandes homens, aprendido por mim com uma longa experiência das coisas modernas e uma contínua leitura das antigas, as quais, tendo-as eu com grande diligência longamente excogitado e examinado, e agora resumido num pequeno volume, mando a Vossa Magnificência. (MAQUIAVEL, 2017 p. 85)
\end{abstract}

Neste prólogo está indicado o conteúdo de sua oferta: "o conhecimento das ações dos grandes homens" fundamentado em duas raízes "aprendido por mim com uma longa experiência das coisas modernas e uma contínua leitura das antigas". Também a intenção personalíssima de obter o favor de Lourenço está presente ao final da dedicatória: "E, se vossa Magnificência, lá do ápice de sua alteza, alguma vez virar os olhos para estes baixos lugares, conhecerá quanto eu imerecidamente suporto grande e contínua malignidade da fortuna." (MAQUIAVEL, 2017 p. 87).

Das recomendações inicias destacam-se as informações que transparecem como o objeto da obra. De modo claro em São Tomás dois temas se apresentam: a origem do governo e aquilo que compete ao ofício do rei. Em Maquiavel apenas aparece o enigmático "conhecimento das ações dos grandes homens". Mas a diferença de estilo esconde a semelhança de conteúdo. Já no primeiros capítulo do "Principe" a temática sobre a origem do governo e do ofício de governar, tal qual em São Tomás, se faz perceber. "Quantos são os gêneros de principados e de que modo se adquirem" (MAQUIAVEL, 2017 p. 91) é seu título. A questão posta pelo título se desenvolve nos capítulos seguintes, discorrendo o autor sobre a origem dos governos

FILHO, José Arlindo de Aguiar. A política no fim da idade média e sua influência no renascimento: entre o "De regno - ad regem cypri", de São Tomás, e "Il principe", de Maquiavel. Griot : Revista de Filosofia, Amargosa - BA, v.19, n.2, p.265-283, junho, 2019. 
e analisando as ações que lhes proporcionaram sucessos e fracassos ${ }^{6}$. E ao fechar a temática inicia o capítulo 12 resumindo o que realizou e, aqui sim com alguma clareza, pondo à luz o significado das ações a que se refere no prólogo e que continuará a escrutinar nos capítulos seguintes:

Tendo exposto em pormenor todas as qualidades dos principados que, no início, me propus a discutir, e tendo considerado sob alguns aspectos as causas do seu bem-estar e do seu mal-estar, e mostrando os modos com que muitos procuraram adquiri-los e detê-los, resta-me agora expor genericamente os meios ofensivos e defensivos que em cada um dos prémencionados pode haver. (MAQUIAVEL, 2017 p. 165)

Observe-se a divisão feita nas "ações dos grandes homens" revelada no parágrafo: ações para conquistar o poder, e ações para manter o poder. As ações de conquista podem ser a fundação de um novo principado ou o tornar-se príncipe em um estado já existente. As ações de manutenção envolvem o ofício precípuo do governo. A divisão é a mesma que encontramos no capítulo 14 de Tomás: "está compreendida também na função régia a instituição da cidade ou do reino [...] Da mesma sorte compete, outrossim, ao ofício de governo o conservar o que é governado $[\ldots] "$ (AQUINO, 1995, p.160).

Outro argumento em favor da semelhança de objeto é considerar quem são os "grandes homens" de quem Maquiavel fala. São estadistas como Rômulo, Júlio César, Tito, Moisés e Davi, por exemplo. As ações sobre as quais fala e conhece são ações de governo, pertencem ao ofício de governar. Maquiavel e Tomás falam dos mesmos homens (todos os exemplificados acima são citados na obra de Tomás) ${ }^{7}$, e das mesmas ações, relativas ao mesmo ofício. O objeto, nos dois textos, é semelhante. A segunda informação relevante retirada da comparação dos trechos iniciais é a base que cada autor usa para fundamentar sua visão sobre os reinos e as ações dos reis. Em Tomás, e seguindo a ordem: "as divinas Escrituras, ensinamentos dos filósofos, e exemplo dos príncipes". Em Maquiavel, também em ordem, "experiência das coisas modernas e uma contínua leitura das antigas". Aqui, apesar dos três elementos apresentados por Tomás e dois por Maquiavel, há uma ampliação do segundo em relação ao primeiro. Maquiavel, na verdade, acrescenta uma fonte primária ao modelo de Tomás. No "Principe", nas remissões ao conhecimento antigo, encontramos o uso das escrituras ${ }^{8}$, o ensinamento dos filósofos ${ }^{9}$ e o exemplo dos príncipes. O primeiro elemento apresentado no "Principe" engloba os três

\footnotetext{
${ }^{6}$ Os tipos em que se dividem os principados são: principados hereditários no cap. 2, principados mistos no 3 , obtidos pelas armas próprias no 6 , obtidos através de armas alheias no 7, obtidos pelo crime no 8 , principado civil no 9 , e, por fim, os eclesiásticos no 11.

7 Os nomes citados encontram-se respectivamente nas obras de Tomás e Maquiavel nas páginas indicadas a seguir. Rômulo: 160, 169 de Tomás; 121, 123, 125 de Maquiavel. Júlio César: 153, 165 de Tomás; 181, 189 de Maquiavel. Davi: 148 de Tomás; 175 de Maquiavel. Moisés: 161 de Tomás; 121, 123, 125, 251 de Maquiavel.

${ }^{8} \mathrm{O}$ exemplo mais emblemático é a figura do profeta Moisés na famosa comparação com Savonarola (2017, p. 123125)

${ }^{9}$ Há apenas uma citação do grego Xenofonte (2017 p.181), porém, entre os comentadores é defendida a influência latina de Cícero contra o pensamento clássico aristotélico (STRAUSS, 2015 p. 121-122), e de Boécio na base dos conceitos de Virtu e Fortuna (BIGNOTTO, 1991 p. 141-143). Enfim, a falta de citação direta não é obstáculo para garantir a presença do ensinamento dos filósofos, mesmo que não os mesmos de Tomás, na obra de Maquiavel.
}

FILHO, José Arlindo de Aguiar. A política no fim da idade média e sua influência no renascimento: entre o "De regno - ad regem cypri", de São Tomás, e "Il principe", de Maquiavel. Griot : Revista de Filosofia, Amargosa - BA, v.19, n.2, p.265-283, junho, 2019. 
apresentados no "De Regno". A experiência prática de Maquiavel na política é o diferencial entre as fontes em que se apoiam as obras.

\section{Definições, capítulos 2-12 de Tomás}

A definição de rei de São Tomás se encontra no final do capítulo 2: "Do que foi dito fica patente ser rei aquele único que governa, para o bem comum, a multidão de uma cidade ou país." (AQUINO, 1995 p.130) Este conceito traz consigo um critério ético de separação entre os tipos de governante. Há bons e maus governantes de acordo com sua atenção ao bem comum. "Se, pois, a multidão dos livres é ordenada pelo governante ao bem comum da multidão, o regime será reto e justo, como aos livres convém. Se, contudo, o governo se ordenar não ao bem comum da multidão, mas ao bem privado do governante, será injusto e perverso o governo." (AQUINO, 1995 p.128). Para o governante ser considerado rei, na definição de Tomás, é essencial que governe para o bem comum. Apenas o bom governante, sendo bom o que busca o bem comum, é rei; restando o lado excluído da definição ao tirano. "Caso, então, seja exercido por um só o governo injusto, buscando pelo governo os seus interesses e não o bem da multidão a si sujeita, tal governante se chama tirano" (AQUINO, 1995 p.129).

Há duas informações importantes a destacar da definição. Primeiro é a existência de um vínculo ético entre o governante e sua finalidade para definir o rei. Ética e política já no princípio do "De Regno" se colocam de modo interligado. Segundo é a necessidade do conceito de bem comum, cuja busca se relaciona à atividade política por um lado, e, por outro, é o critério ético de diferença entre o rei, o bom e verdadeiro político, e o tirano.

Há no "Principe" um tratamento diferente quanto ao conceito de "rei". Maquiavel não anuncia uma definição explícita do rei, que chama de príncipe ${ }^{10}$. A definição inicial é a do principado. E a relação imediata do governante com um critério moral não existe. Mas, a partir do principado, o florentino diz o que considera ser o príncipe e mostra seu entendimento sobre a relação do governante com a moralidade, e com o bem comum, através de seus exemplos.

"Todos os estados, todos os domínios, que tiveram ou tem império sobre os homens, foram e são repúblicas ou principados." (MAQUIAVEL, 2017 p. 91) Esta é a primeira frase do primeiro capítulo. $O$ príncipe é simplesmente o governante de um principado. A questão do governo das repúblicas é tratada em outra obra ${ }^{11}$. Analisando o modo de adquirir o principado, de tornar-se príncipe, pode-se já distanciar o pensamento maquiavélico do tomasiano: não há nenhuma necessidade de ser bom, ou melhor, de buscar o bem comum, para que um homem, ou ainda um vilão criminoso, torne-se príncipe. Isso é patente em diversos pontos da obra, como, por exemplo, no capítulo cujo título confirma: “Aqueles que por crimes atingiram o

\footnotetext{
10 Os termos "rei" do "De Regno" e "príncipe" do "Il Principe" não são intercambiáveis. O primeiro será sempre usado para referir-se às ideias de Tomás, o segundo para as de Maquiavel. E nos trechos de análise serão trocados pela caracterização "governante" sem referir-se a nenhuma das definições especificamente e podendo abarca-las a depender do contexto.

11 Os Discorsi (MAQUIAVEL, 1994), provável referência inicial do capitulo 2 "Deixarei de lado o discutir as repúblicas, visto que já uma outra vez discuti longamente sobre isso.” (MAQUIAVEL, 2017 p.93)
}

FILHO, José Arlindo de Aguiar. A política no fim da idade média e sua influência no renascimento: entre o "De regno - ad regem cypri", de São Tomás, e "Il principe", de Maquiavel. Griot : Revista de Filosofia, Amargosa - BA, v.19, n.2, p.265-283, junho, 2019. 
principado" (MAQUIAVEL, 2017 p. 139). E ainda mais além: não apenas podemos dizer que ser bom não está incluído na definição de príncipe como para ser príncipe é necessário o contrário, não ser bom!

\begin{abstract}
Muitos imaginaram repúblicas e principados que jamais se viu ou conheceu existirem de verdade. Porque é tanta a distância de como se vive a como se deveria viver, que aquele que deixa o que se faz por aquilo que se deveria fazer mais depressa aprende a ruína do que sua preservação: porque um homem que em todos os aspectos queira fazer profissão de bom tem de se arruinar entre tantos que não são bons. Donde é necessário, querendo-se um príncipe manter, aprender a poder ser não bom e usá-lo e não o usar consoante a necessidade. (MAQUIAVEL, 2017 p. 183)
\end{abstract}

Na comparação entre as definições observe-se: Maquiavel reduz o conceito de rei do pensamento tomista. $O$ rei de Tomás é o governante para o bem comum; o príncipe de Maquiavel é o governante, apenas. A questão que submerge desta redução é: Qual o lugar do juízo de valor na concepção do governante? Tomás julga o rei e o tirano como opostos morais. A oposição moral em Maquiavel tem uma nuance política mais pragmática: Maquiavel julga o príncipe incompetente em sua função como oposto "moral" do príncipe competente.

Nos capítulos 3 até o 6, o "De Regno" constrói os argumentos que buscam demonstrar o lugar do rei e do tirano numa hierarquia política. Para tanto se vale do modelo aristotélico (Política, IV, 2, 1289 a, 26 - 1289 b, 4. 1995 p. 2046) que estratifica os tipos de governo, em ordem do melhor para o pior, em Monarquia, Aristocracia, Politia, Democracia, Oligarquia e Tirania ${ }^{12}$. Como de costume, na sua obra rigidamente construída, o critério de classificação necessário para resolver a questão é imediatamente colocado. Esta é a primeira frase do capítulo 3: "cumpre indagar o que mais convém ao país ou à cidade: ser governado por muitos ou por um só. E isto se pode considerar a partir do próprio fim do governo." (AQUINO, 1995 p. 130) A finalidade do governo é a base que estabelece a hierarquia entre seus tipos. Aqui há um duplo desdobramento: primeiro, o critério de Tomás precisa acrescentar um elemento muito presente em Maquiavel, a eficiência; segundo, é preciso estabelecer qual é a finalidade do governo.

Deve ser a intenção de qualquer governante o procurar a salvação daquele cujo governo recebeu. Pois, compete ao piloto conduzir ilesa ao porto de salvamento a nave, guardando-a contra perigos do mar. Ora, o bem e salvamento da multidão consorciada é conservar-lhe a unidade, dita paz, perdida a qual, perece a utilidade da vida social, uma vez que é onerosa a si mesma a multidão dissensiosa. Por conseguinte, o máximo intento do governante deve ser o cuidar da unidade da paz. (AQUINO, 1995 p.130)

A classificação segue, portanto, um princípio: o melhor governo é aquele que melhor atinge a finalidade da existência de um governo: a paz. Maquiavel, em certa medida, converge com Tomás. Converge no critério da competência para perseguir os objetivos e também, parcialmente, na caracterização da finalidade do príncipe.

${ }^{12}$ Foi mantida a terminologia utilizada na obra citada de Tomás (1995). Ver nota 1.

FILHO, José Arlindo de Aguiar. A política no fim da idade média e sua influência no renascimento: entre o "De regno - ad regem cypri", de São Tomás, e "Il principe", de Maquiavel. Griot : Revista de Filosofia, Amargosa - BA, v.19, n.2, p.265-283, junho, 2019. 
A estabilidade e a segurança proporcionadas por um governo forte são os fins que justificam os meios empregados para obtê-las. Interessante notar que Maquiavel refere-se ao príncipe, no derradeiro capítulo da obra, em termos quase idênticos a Tomás. O capítulo clama por um redentor para salvar a Itália. O objetivo do príncipe para quem as instruções foram escritas é trazer "honra a ele e bem ao conjunto dos homens" (MAQUIAVEL, 2017 p. 251). O objetivo é equivalente ao "salvamento da multidão consorciada" de Tomás, com a adição do bem privado, a honra. Este é o ponto comparativo importante da seção formada pelos capítulos 3-6: a parcial semelhança entre os autores na concordância sobre a finalidade do governo. Tanto Tomás quanto Maquiavel julgam como "bom" um governo capaz de manter a paz em um país, tanto internamente quanto externamente. A divergência aparecerá quando ficar explícito o modo como os autores acreditam dever proceder os governantes para obter esse resultado.

Tomás segue, até o fim do trecho, na construção argumentativa de sua versão do modelo aristotélico (inclusive citando o próprio Aristóteles) (AQUINO, 1995 p.134), utilizando diversas passagens bíblicas, elogiando o modelo da república romana $^{13}$ e também citando Agostinho ${ }^{14}$. $\mathrm{O}$ estabelecimento do modelo termina no capítulo 6, após o elogio da monarquia, e, a crítica da democracia ${ }^{15}$.

No capítulo 7 surge um fator que não pode mais ser conciliado com o modelo aristotélico: o cristianismo. Apesar de estar presente no texto desde seu início, é aqui que sua posição estrutural separa Tomás da Grécia, e de uma forma muito interessante: na defesa da tirania. "Se não for excessiva a tirania, mais conveniente é temporariamente tolerá-la branda, do que, na oposição ao tirano, ficar-se emaranhado em muitos perigos piores que a tirania." (AQUINO, 1995 p. 139). A presença do cristianismo na estrutura conceitual do pensamento político seguirá através dos capítulos 8-12, de modo original e instigante, quando Tomás analisa, para o caso do governante, a relação da finalidade privada com a finalidade pública, através da ideia de recompensa ou castigo a serem recebidos por exercer, bem ou mal, sua função.

A tirania por vezes deve ser tolerada, pois derrubá-la muitas vezes dá lugar a outra pior. A "boa" tirania oprime menos o povo, e, o processo de substituição, o caos da falta de governo e da instabilidade política a ser atravessado, é mais nocivo que uma opressão moderada. Um governante inescrupuloso e mau pode ser melhor que a falta de governo. Além disso, o tirano é um castigo divino. Tolerar o tirano é uma graça e uma penitência.

devemos ser reverentemente submissos, tanto aos senhores bons e moderados, como também aos perversos. É, de fato, uma graça se alguém

\footnotetext{
${ }^{13}$ Uma referência positiva análoga a de Maquiavel (1994) na sua obra sobre as repúblicas, os Discorsi.

${ }^{14}$ De Boni afirma sobre o texto, principalmente a partir do capitulo cinco. "Tomás está lendo Aristóteles com os óculos de Agostinho e da tradição cristã. [...] o quinto [capítulo] inicia-se com um tema logicamente estranho a Aristóteles: uma recapitulação da história das mudanças na forma de governo entre os romanos. A partir daí, o fio condutor passa a ser Agostinho, principalmente através do livro 5 do De civitate Dei." (DE BONI, 2004 p. $320)$

15 Neste capítulo Tomás parece profetizar a crise de representatividade das democracias modernas na América Latina: "E, se alguém considerar diligentemente, em todo o mundo, os fatos passados e os que ora se dão, há de achar ter havido mais tiranos nas terras governadas por muitos do que nas governadas por um só" (AQUINO, 1995 p.138)
}

FILHO, José Arlindo de Aguiar. A política no fim da idade média e sua influência no renascimento: entre o "De regno - ad regem cypri", de São Tomás, e "Il principe", de Maquiavel. Griot : Revista de Filosofia, Amargosa - BA, v.19, n.2, p.265-283, junho, 2019. 
permanece firme e sofre molestações injustas, para dar testemunho de Deus, razão por que, quando muitos imperadores romanos perseguiram tiranicamente a fé cristã, sendo já convertida a ela grande multidão tanto de nobres como de povo, são louvados não por resistirem, senão por padecerem pacientemente mesmo armados a morte por Cristo. (AQUINO, 1995 p.140)

Apenas numa cosmologia cristã seria possível essa argumentação. "Deus permite que governem os tiranos para punir os pecados dos súditos" (AQUINO, 1995 p. 155). Nesse raciocínio, o povo é duplamente oprimido: pelo tirano, e pela culpa, restando-lhe a resignação penitencial como saída. O conselho para o povo de tolerância como virtude cinde o pensamento de Tomás e de Maquiavel. A cosmovisão cristã de recompensas fora desse mundo é impossível para o florentino.

Para Maquiavel (2017 p. 147) o desejo do povo é não ser oprimido. Por isso suas ações refletem a luta para realizar essa vontade. Um tirano pode ser bom sim, pelo mesmo motivo apontado por Tomás - evitar a falta de governo e maior sofrimento do povo. Mas a atitude e recompensa esperada pela multidão não pode ser o prêmio da vida eterna. A luta entre o povo e os poderosos para fazer valer suas vontades deve ser administrada pelo príncipe de modo a gerar um equilíbrio. $O$ equilíbrio entre o governante e o povo em Tomás é estático - o povo e o rei desejam o mesmo (recompensa do além) e cabe a um governar e ao outro tolerar. Em Maquiavel esse equilíbrio é dinâmico, da luta entre opressores e oprimidos nasce um ponto de equivalência, através do príncipe, que harmoniza o Estado numa dialética estável.

No capítulo 8 encontra-se o início de uma discussão interessantíssima: o prêmio do rei. Tomás afasta-se textualmente de Aristóteles e do saber antigo ao negar que a opinião deles esteja correta quanto a esse assunto. É preciso cuidado neste ponto do texto, seguem as palavras iniciais do capítulo: "Posto que, segundo vai dito, cumpre ao rei procurar o bem da multidão, parece excessivamente oneroso o cargo de rei, a não ser que lhe advenha disso algum bem próprio." (AQUINO, 1995 p. 142)

Tomás, de modo relutante, reconhece que só haverá rei se houver um prêmio. E aqui não nos referimos ao governante, seja um bom rei ou um tirano, Tomás fala do rei, o homem bom que trabalha pelo bem comum, o homem cuja finalidade é atingir o bem comum. Esse homem só existirá se houver para ele uma recompensa. Oras, até que ponto então estará ele buscando o bem comum? Buscará ser bom para ganhar seu prêmio? Assim sendo a finalidade do rei não é o bem comum, este é apenas o meio para seu bem privado. Este problema não encontra solução aqui, há uma tentativa em capítulo posterior que mais tarde será analisada.

No parágrafo subsequente, Tomás cita as fontes contra as quais irá sobrepor sua opinião acerca da recompensa do rei:

A certos pareceu-lhes não ser outro que a honra e a glória, donde chegar Túlio (A República; cf. Agostinho, Cidade de Deus, V, 13) a definir que o príncipe da cidade deve nutrir-se de glória, razão do que parece indicar Aristóteles na Ética (V, 10, 1134 b 6-8), pois o príncipe, a quem não basta honra e glória, torna-se em consequência um tirano, visto ser inerente ao espírito de todos procurar o próprio bem. (AQUINO, 1995 p. 142)

FILHO, José Arlindo de Aguiar. A política no fim da idade média e sua influência no renascimento: entre o "De regno - ad regem cypri", de São Tomás, e "Il principe", de Maquiavel. Griot : Revista de Filosofia, Amargosa - BA, v.19, n.2, p.265-283, junho, 2019. 
Neste ponto específico, Maquiavel se mostra mais aristotélico que Tomás. A honra e a glória são a recompensa do grande fundador, dos grandes príncipes. "honra a ele e bem ao conjunto dos homens" (MAQUIAVEL, 2017 p. 251). A finalidade do governante é seu bem privado, e o único bem privado que gera, como efeito colateral o bem comum - que é o meio para atingi-la - é a glória.

O julgamento de valor que em Tomás separa reis e tiranos tem um equivalente sutil nas páginas do "Príncipe". No capítulo que trata dos príncipes que atingem o poder através dos crimes o florentino anota sobre Agástocles (que de "ínfima e abjeta origem, tornou-se rei de Siracusa"):

\begin{abstract}
Se se considerar, então, as ações e a vida deste, não verá nada, ou quase nada, que possa ser atribuído à sorte; como se disse acima, não pelo favor de alguém, mas subindo os graus da milícia com muitos dissabores e perigos, conquistou o principado, que depois manteve com tantas decisões audazes e perigosas. Não se pode também chamar de virtude o fato de matar cidadãos, trair amigos, não ter fé, nem piedade, nem religião; desse modo pode-se conquistar o poder, mas não a glória. (MAQUIAVEL, 2008, $68)^{16}$
\end{abstract}

Agástocles foi um governante eficiente, mas não glorioso. $O$ equivalente da definição tomasiana de rei, o governante direcionado ao bem comum, é o príncipe glorioso. Atenção: não é o príncipe bom, glória e bondade não são equivalentes. Maquiavel corta o problema da finalidade ambígua, presente em Tomás, para ele o rei tem um propósito privado, egoísta: a glória, atingida através da promoção do bem comum. $O$ tirano também tem um propósito privado: o poder, ou as riquezas, atingidos através da opressão.

Esta ideia está articulada de forma brilhante no texto de Leo Strauss sobre Maquiavel:

O único desejo egoísta que pode induzir os homens a estar apaixonadamente preocupados com o bem-estar da posteridade remota é o desejo de glória perpétua ou imortal. O desejo por essa glória é o laço existente entre a maldade e a bondade, uma vez que, embora egoísta em si mesmo, ele não pode ficar satisfeito com qualquer outra coisa que não o maior serviço possível aos outros. (STRAUSS, 2015 p. 349)

A busca do bem privado, da recompensa régia, em Maquiavel se resolve com a solução antiga: o governante que, além de eficiente, mostre-se cioso pelo bem comum, atingirá a glória.

Mas Tomás recusa esse caminho. Sua argumentação tem dois passos principais: ainda no capítulo 8 tenta demonstrar como a glória é um prêmio pobre, fraco e incapaz de mobilizar um homem a sacrificar outros bens privados em nome do bem comum; e, no capítulo 9, introduz uma divisão que amplia o conceito de

${ }^{16}$ Curioso observar a nota, presente nesta tradução, que Napoleão fez para o trecho: "Meras preocupações pueris. A honra acompanha sempre o êxito seja qual for o meio empregado para obtê-lo.". Ao verdadeiro príncipe, Maquiavel parece preocupado demais com a ética.

FILHO, José Arlindo de Aguiar. A política no fim da idade média e sua influência no renascimento: entre o "De regno-ad regem cypri", de São Tomás, e "Il principe", de Maquiavel. Griot : Revista de Filosofia, Amargosa-BA, v.19, n.2, p.265-283, junho, 2019. 
glória em uma glória inferior, humana, e outra superior, a glória divina - o prêmio adequado ao bom rei.

$\mathrm{O}$ ataque de Tomás à busca pela glória primeiro define este bem como frágil, citando Isaías (Is 40, 6-8) que a chama "flor de feno" por depender das opiniões alheias, sempre volúveis. "Com efeito nada há, ao que parece, mais frágil, entre as coisas humanas, do que a glória e a honra do favor dos homens, pois depende das opiniões e palavras deles, nada havendo de mais mutável em sua vida." (AQUINO, 1995 p.143). Esta visão pessimista, e compartilhada por Maquiavel, sobre a opinião pública, é o primeiro ponto fraco da glória.

Em seguida, Tomás afirma que a verdadeira glória só pode ser atingida por quem a despreza. "Que é próprio da alma forte e virtuosa desprezar, pela justiça, tanto a glória como a vida; donde resulta certa maravilha que, seguindo a glória aos atos virtuosos, a própria glória seja virtuosamente desprezada e, pelo menosprezo dela, se torne glorioso o homem." (AQUINO, 1995 p.143). Portanto, o homem que almeja tornar-se glorioso estará automaticamente impossibilitado de atingir sua meta. O modelo maquiavélico, tomando verdadeira esta posição, é um caminho para a frustração.

A terceira fraqueza da glória é o perigo que ela representa para a segurança do rei. Um rei que ambiciona tornar-se glorioso corre o risco de influenciar suas decisões de maneira prejudicial, deixando de evitar perigos e possíveis danos por promessas de glória.

O último ataque é o mais interessante em termos de possibilidades de comparação com Maquiavel. A glória faz dos homens dissimuladores (portanto, diria o florentino, príncipes eficientes). "Tem ainda, a paixão da glória, um outro vício a ela familiar: a dissimulação, porquanto, sendo difícil e a poucos dado o seguir as virtudes verdadeiras, somente às quais se deve honra, muitos ambiciosos da glória se fazem simuladores." (AQUINO, 1995 p.144).

Maquiavel concorda que a busca da glória torna homens em dissimuladores. E isto é uma boa coisa no caso dos príncipes, como comprova todo o capítulo 18 de seu livro (MAQUIAVEL, 2017 p. 199). Pois, para exercerem com eficiência seu ofício, precisam mobilizar a opinião alheia. A precariedade da opinião pública só pode tornar-se menos danosa se direcionada através da habilidade do príncipe para a estabilidade do estado. Imagine como viveriam os reinos que trocam de governante de acordo com as mudanças de opinião do povo: numa instabilidade política que traria danos para o próprio povo emissor dessas mutantes opiniões. Esse é o caso em diversos países hoje.

Portanto, para Maquiavel, a glória não deve ser desprezada, afinal, na maioria das vezes, é necessário um esforço ativo para obtê-la: o uso competente da habilidade de dissimular. Excetuando casos muitos raros em que um príncipe tenha sorte suficiente para viver um momento em que não haja necessidade de mentir para garantir a estabilidade da opinião pública. A gloria do mentiroso e a do afortunado que jamais precisou mentir para manter o poder é idêntica - sendo que deveria ser maior no caso do dissimulador que mostrou maior habilidade para conquista-la que um mero sortudo. A opinião pública, a voz do povo, é o lugar onde nasce a glória. $O$ príncipe eficiente não despreza a opinião do povo. Suas mentiras são a prova do respeito que tem pela importância dessa opinião.

FILHO, José Arlindo de Aguiar. A política no fim da idade média e sua influência no renascimento: entre o "De regno - ad regem cypri", de São Tomás, e "Il principe", de Maquiavel. Griot : Revista de Filosofia, Amargosa - BA, v.19, n.2, p.265-283, junho, 2019. 
E, ironia, esse é um motivo pelo qual o governante deve incentivar a religião entre os seus súditos. Dissimular uma grande fé, dar mostras ao povo de que Deus existe e espera de todos um comportamento submisso em troca de bens celestes, é um ótimo procedimento.

Mas, no fim das contas, Tomás concordará circunstancialmente com Aristóteles e Maquiavel, admitindo ser a glória o melhor dos prêmios terrenos.

Tem a paixão da glória algum vestígio da virtude, ao menos enquanto procura a aprovação dos bons e se recusa a desagradar-lhes. Uma vez, portanto, que poucos chegam à verdadeira virtude, é mais suportável, se for conduzido ao governo alguém que, embora só por temor do juízo dos homens, pelo menos se afasta dos males manifestos. (AQUINO, 1995 p.144)

Num cenário cosmológico sem a presença de Deus, a glória é a única esperança de mobilização do governante para o bem comum.

Após os quatro ataques e o recuo parcial do capítulo 8, Tomás avança na estratégia argumentativa em direção a um resgate e ampliação conceitual da glória no capítulo 9. E nesse capítulo, a cosmologia cristã surge como determinante da política: "Em verdade, é conveniente que de Deus espere o rei seu prêmio." (AQUINO, 1995 p. 145)

O caminho percorrido para defender essa visão cristã de mundo passa por um argumento aristotélico: o maior bem desejado pelo homem é a felicidade (Ética a Nicômaco I, 7, 1097 b 1-7. 1995 p. 1734). Tomás, ao mesmo tempo que, nesse ponto, acaba por reforçar a impressão de que o rei busca seu bem privado através da promoção do bem comum, também cuida de dar interpretação própria ao conceito de felicidade. A felicidade verdadeira precisa estar ligada a única fonte capaz de saciar o desejo máximo da natureza humana. $\mathrm{O}$ desejo é infinito, e, portanto, insaciável ${ }^{17}$. Tudo o que o homem possui logo se torna insuficiente, levando-o a querer cada vez mais. Portanto, a satisfação do desejo infinito só pode ser realizada por um bem infinito: Deus. A busca inteligente do bem privado levará à busca por Deus.

Com efeito, está escrito nas mentes de todos os dotados de razão que o prêmio da virtude é a felicidade. Pois, diz-se da virtude de qualquer coisa, que 'ela torna bom a quem a tem e torna boa sua obra' (Arist., Ética, II, 5, 1106 a 16). A uma coisa se esforça por chegar todo aquele que bem procede, coisa essa que é maximamente apegada em seu desejo: o ser feliz, que ninguém pode deixar de querer. Espera-se, portanto, como prêmio conveniente da virtude, o que torna o homem feliz. Consideremos então em que consiste isso. Denominamos, realmente, felicidade o fim último dos desejos. E o movimento do desejo não procede em infinito; pois seria vazio o desejo natural, visto que os infinitos não podem ser percorridos. Mas, sendo o desejo da natureza intelectual do bem universal, só poderia fazer feliz verdadeiramente aquele bem que, alcançado, não resta mais bem algum que possa desejar. Por onde, se denomina também felicidade o bem perfeito, como abrangendo tudo que é desejável, o qual não é nenhum dos bens terrenos; pois quem possui riquezas deseja ter mais, e os que gozam

17 "nada pode saciar os apetites humanos, pois a natureza nos deu a faculdade de tudo desejar, mas a sorte não nos deixa senão provar poucas coisas" (MAQUIAVEL, 1994 p. 191)

FILHO, José Arlindo de Aguiar. A política no fim da idade média e sua influência no renascimento: entre o "De regno - ad regem cypri", de São Tomás, e "Il principe", de Maquiavel. Griot : Revista de Filosofia, Amargosa - BA, v.19, n.2, p.265-283, junho, 2019. 
de prazeres desejam gozar mais e semelhantemente se patenteia com outras coisas. E se não se buscam mais vastas, não obstante deseja-se que permaneçam, ou outras sucedam em lugar delas. Nada havendo de permanente nas coisas terrenas, nada há de terreno que possa aquietar o desejo. Assim, nada do que é terreno pode fazer feliz, para poder ser prêmio conveniente do rei. (AQUINO, 1995 p. 146-147).

Ao que conclui logo adiante: "Logo, só Deus é quem pode aquietar o desejo do homem e fazê-lo feliz e ser recompensa conveniente ao rei. [...] Pode-se, assim, verificar, portanto, que é honra e glória o prêmio do rei." (AQUINO, 1995 p. 148), mas essa glória é diferente daquela do capítulo 8:

\begin{abstract}
Além disso, que glória de louvor humano pode comparar-se a esta que não profere a língua falsa dos lisonjeadores, nem a opinião precária dos homens, mas procede do testemunho interior da consciência e se confirma pelo testemunho de Deus, que aos seus confessores se compromete a confessá-los na glória do Pai, em face dos anjos de Deus $(L c 12,8)$ ? Os que buscam esta glória, alcançam-na e, mais, conseguem a dos homens que não procuram, a exemplo de Salomão, que não só recebeu do Senhor a sabedoria que buscou, senão também foi feito glorioso acima de todos os outros reis. (AQUINO, 1995 p. 148)
\end{abstract}

Tomás finaliza o raciocínio estabelecendo dois tipos de glória, a de louvor humano, mundana, e a divina, prêmio do bom rei que busca a Deus. A grande diferença e dificuldade aqui é o trecho final, em que afirma categoricamente que o homem ao buscar a glória divina alcança, por tabela, a glória mundana. Este é um ponto sensível que Tomás busca reforçar com alguma insistência, provavelmente para capturar o mínimo de atenção do homem mundano, matéria prima dos reis. Decerto corretamente, afinal não seria razoável esperar que os reis ignorem a busca pelos bens terrenos - que estão a sua mão - em busca de bens celestes. Tomás precisa fazer crer que o bem divino, por mais que seja maravilhoso, vem complementado pelo bem mundano ${ }^{18}$. $\mathrm{O}$ que aparece nos capítulos seguintes.

Nos capítulos 10 a 12 encontra-se uma dupla argumentação que procura convencer o rei de que seu prêmio, a glória celeste, é a melhor das recompensas. A primeira prova é teológica, o maior bem a ser esperado de Deus advém do maior agrado que Lhe podemos causar: promover o bem comum. À maior virtude corresponde o maior prêmio. Porém neste primeiro passo da argumentação chama à atenção um parágrafo em que Tomás excede o tema e coloca uma reflexão interessante que traz implicações para a questão da relação entre bem privado e bem público:

Ora, o bem da multidão é maior e mais divino que o de um só; por essa causa, tolera-se às vezes o mal de um só, se aproveita ao bem da multidão; por exemplo, mata-se o ladrão, para dar paz à multidão. Não permitiria o próprio Deus que males houvesse no mundo, a não ser que, deles, tirasse bens para a utilidade e beleza do universo. (AQUINO, 1995 p. 150).

\footnotetext{
18 Maquiavel não partilha do mesmo pensamento. O célebre exemplo de Savonarola, o profeta desarmado, expõe essa opinião. Os homens que se fiaram nas promessas divinas sem preparar seu exército fracassaram. Apenas profetas armados atingem bens mundanos. (MAQUIAVEL, 2017 p. 123-125)
}

FILHO, José Arlindo de Aguiar. A política no fim da idade média e sua influência no renascimento: entre o "De regno - ad regem cypri", de São Tomás, e "Il principe", de Maquiavel. Griot : Revista de Filosofia, Amargosa - BA, v.19, n.2, p.265-283, junho, 2019. 
Maquiavel diria: o mal está justificado, como meio, por seu fim: a paz, o bem. A boa finalidade, justifica os males úteis para sua obtenção. $O$ bem público justifica o mal privado. Quantos passos seriam dados para chegar ao príncipe cruel nas guerras, mentiroso e sedento de glória, que é um mal útil para promover um estado forte, pacífico e bom para seus habitantes?

No capítulo 11, em complemento ao 10, do mesmo modo como procedeu nos ataques à glória mundana para depois recuar parcialmente, Tomás fala dos bens mundanos com os quais certamente será recompensado o bom rei. Uma lista muito útil para o caso do governante não achar que a promessa de glória divina seja prêmio suficiente, e que demonstra uma fina sabedoria prática na política de Tomás. $O$ bom rei recebe o amor dos súditos, recebe fama através desse amor, e dinheiro através das economias que fará na segurança interna do reino também resultante desse amor. Daí conclui Tomás que é melhor ser amado que temido (AQUINO, 1995 p.154). Ao que Maquiavel simplesmente responderia ser uma ingenuidade fiar-se no amor do povo, e mesmo concordando que é imperioso evitar ser odiado, conclui que é melhor ser temido exatamente por não poder confiar nos sentimentos e opiniões do vulgo. "É muito mais seguro ser temido que amado. Porque dos homens pode-se dizer que, no geral, são ingratos, volúveis, simuladores e dissimuladores, arredios aos perigos, ávidos do lucro." (MAQUIAVEL, 2017 p. 193)

O ponto final da argumentação de Tomás sobre o prêmio do rei está no capítulo 12. Aqui Tomás descreve sucintamente terrores e suplícios que aguardam o tirano. Já para os reis Deus destina as recompensas divinas e também mundanas. Um complemento teológico para os pontos levantados no capítulo 11.

\footnotetext{
Se, pois, para os reis os bens temporais abundam; se lhes é preparado por Deus um grau excelso de beatitude, ao passo que aos tiranos se lhes frustram, as mais das vezes, os bens temporais que ambicionam, sobre jazerem sob muitos perigos temporais e, o que é mais, ficarem privados dos bens eternos, reservando-se-lhes as mais graves penas, devem veementemente diligenciar, os que recebem o encargo de governar, por dar-se aos súditos como reis, e não como tiranos. (AQUINO, 1995 p. 158)
}

Aqui Tomás encerra sua definição de rei. Sua estrutura sistemática de pensamento já condensa na definição o fundamento dos corolários que seguem o conceito. Daí a importância de expor as características do rei e abrir caminho para delas retirar com clareza as implicações subsequentes. No caso, sua função e modo apropriado de agir. Tomás realiza essa tarefa com maestria, e vai além: encontra espaço para retoricamente buscar o convencimento dos benefícios que seu modelo pode trazer caso algum governante de carne e osso se interesse por levá-la a sério.

As características do rei são a posse da posição de mando, ser um governante, uma circunstância política, e, ser bom, no sentido moral, em seu governo, uma circunstância ética. No caso do governante, o "ser bom" pode ser entendido como a promoção do bem comum - que precisa ser melhor especificado, e será mais à frente no livro. Através de fortes argumentos teológicos, e discutíveis argumentos políticoeconômicos, Tomás tenta convencer seu leitor que a adesão a este modelo trará benefícios privados ao governante. Benefícios celestes, e benefícios mundanos. $\mathrm{E}$ nessa tentativa talvez esteja mascarada a verdadeira possibilidade de uma política: a

FILHO, José Arlindo de Aguiar. A política no fim da idade média e sua influência no renascimento: entre o "De regno - ad regem cypri", de São Tomás, e "Il principe", de Maquiavel. Griot : Revista de Filosofia, Amargosa - BA, v.19, n.2, p.265-283, junho, 2019. 
busca pela motivação privada para a realização do bem comum. Estabelecer este problema antecipa a política moderna que em Maquiavel se manifesta com absoluta clareza, já liberta da estrutura ético-teológica. Política é a arte de estabelecer o equilíbrio entre a luta pelo benefício privado no campo da coletividade, e como dessa luta pode, e deve, surgir o benefício comum.

\title{
Ofício do governante, Tomás 13-16, Maquiavel 14-26
}

A partir do capitulo 13 até o 16 Tomás escreve sobre a função do rei. Nesse assunto, seu ponto de partida teológico o leva a resultados bastante práticos, o que por vezes se observou nos capítulos anteriores (a glória mundana como recompensa dos reis), por vezes nem tanto (o caráter penitencial da atitude do povo frente ao tirano).

Seguindo a definição do rei como bom governante Tomás usa um espelho elevado para observar o que é governar e o que é governar bem: Deus. Deus governa o universo, e governa bem. A função de Deus é governar o mundo, como a função da cabeça é governar o corpo, e a função do rei é governar o povo. Mas, até aqui, pouco se diz sobre os detalhes da função de governar. $O$ capítulo 13 apenas estabelece a premissa, a analogia do rei com Deus, ponderando ser o bom governante um preposto que exercerá o julgamento no lugar de Deus (AQUINO, 1995 p. 159).

No capítulo 14 a analogia se enraíza no Genesis: Deus cria e conserva o universo. $O$ rei cria e conserva o Estado. Destas duas funções derivam dois tipos de reis, os fundadores e os reis mais propriamente ditos. Pois, todo rei trata de conservar o Estado, mas nem todo rei funda um:

\begin{abstract}
Ora, duas obras de Deus no mundo se hão de considerar, em geral: uma, pela qual Ele cria o mundo; outra, pela qual governa o mundo criado. [...] Destas duas obras, a segunda é que pertence mais propriamente à função real. Assim, pertence a todos os reis o governo, e do regime de governo recebe o nome de rei. Quanto à primeira obra, aliás, não convém a todos os reis. Que nem todos eles instituem o reino ou cidade em que reinam, mas tomam a si o cuidado do governo do reino ou cidade já instituídos. (AQUINO, 1995, p. 160)
\end{abstract}

A divisão é exatamente a mesma que aparece em Maquiavel ao separar os príncipes comuns dos arquétipos fundadores. Aos fundadores cabe a maior glória, porém o trabalho mais difícil é o de conservar sua obra contra a corrupção ${ }^{19}$. A discussão decorrente da divisão envolve a comparação do princípio da re-fundação como essência da atividade de conservação. Um retorno, de algum modo, ao momento e estado pré-estatais para movimentar restaurar o desgaste natural da corrupção inerente à convivência política. Em Maquiavel, portanto, o príncipe que conserva o estado, precisa para tanto ser também um fundador num sentido retroativo. A ideia está presente em Strauss (2015 p. 340-341) e Bignotto (1991 p. 197-198), e foge em proporção ao tratamento tomasiano, mas com ele compartilha a

19 Conferir o capítulo 11 dos Discorsi a primazia de Numa sobre seu predecessor Rômulo, o fundador de Roma. (MAQUIAVEL, 1994 p. 57-59)

FILHO, José Arlindo de Aguiar. A política no fim da idade média e sua influência no renascimento: entre o "De regno - ad regem cypri", de São Tomás, e "Il principe", de Maquiavel. Griot : Revista de Filosofia, Amargosa - BA, v.19, n.2, p.265-283, junho, 2019. 
base: a caracterização dupla da atividade de fundação e refundação (ou conservação contra a corrupção) do governante.

Mas Tomás vai além. Na descrição da boa fundação se esconde o conceito prático de bem comum que sustenta toda a função real. O rei deve: garantir subsistência com fertilidade, garantir o deleite com amenidades, e garantir segurança com as defesas (AQUINO, 1995 p. 161). Pois Deus cria (produz) o universo, como o rei deve produzir o alimento e o crescimento da população; e Deus separa as criaturas em seus lugares, como o rei separa e designa juízes, sacerdotes e guerreiros. A caracterização do conceito se desdobra posteriormente, no capítulo 16.

Terminado o capítulo 14 surge uma divisão clara entre o 15 e o 16.0 capítulo 15 desvia a temática da função real para discutir um tema específico da época: a questão do poder do papa sobre o imperador, o cesaropapismo ${ }^{20}$. Tomás usa o argumento da hierarquia dos fins (espirituais acima dos temporais) para justificar que o papa é o verdadeiro governante do mundo terreno. Mas, do mesmo modo como tratou a questão da glória e das recompensas terenas dos reis, Tomás também retoma a questão prática do bem comum terreno que deve ser alcançado, mesmo que como meio para o bem comum divino que justifica a primazia papal. E é sobre o caminho para esse bem terreno que escreve o capítulo 16, retomando o raciocínio que desviou para a questão do cesaropapismo sumariamente decidida no capítulo 15.

Seja como for, o objetivo do bem comum terreno, que é o que interessa na política moderna, encontrou uma caracterização prática: segurança, deleite e subsistência. Maquiavel concordaria com essas características do bem comum. E seguindo o raciocínio de modo surpreendentemente prático Tomás antecipa receitas para indicar os meios que servem à realização desses fins.

Em um exercício de simetria o pensamento de Tomás articula os três aspectos do bem comum com três atividades do rei, três perigos ou obstáculos, e três soluções para eles.

As atividades são: para garantir segurança, unir a multidão em paz; para garantir o deleite, dirigir a multidão a proceder bem; para garantir a subsistência, prover a multidão de bens necessários.

Os obstáculos a essas atividades são: a vida curta do governante (corrupção do corpo); a maldade da vontade, indolência e perversidade do povo (perigo interno do Estado); os inimigos de outras cidades (perigo externo ao Estado).

E os cuidados para cada obstáculo são: Para a morte do rei, a preparação de uma boa sucessão; para o perigo interno, o estabelecimento de boas leis - bons prêmios e boas penas; e para o perigo externo, boa defesa, um bom exército.

Portanto a função real pode ser assim colocada: o bom rei deve instaurar leis, punindo e premiando, deve fortalecer suas defesas, e garantir sua sucessão. Assim poderá dar ao povo segurança, subsistência e deleite. E receberá seu prêmio: glória e riqueza na terra, e se além de tudo isso, dirigir o povo para a virtude cristã, receberá também a glória divina.

Em resumo, o capítulo 16 é um sumário do "Principe". O bem comum terreno implica a preparação inteligente para solucionar, com a força e com a astúcia, os

20 Para uma discussão pormenorizada sobre o desenvolvimento histórico desse dualismo conferir COSTA; PATRIOTA (2004).

FILHO, José Arlindo de Aguiar. A política no fim da idade média e sua influência no renascimento: entre o "De regno - ad regem cypri", de São Tomás, e "Il principe", de Maquiavel. Griot : Revista de Filosofia, Amargosa - BA, v.19, n.2, p.265-283, junho, 2019. 
problemas da cidade, mesmo após a morte do governante. Este capítulo poderia estar na obra maquiavélica, e prova a sabedoria e agudeza da percepção política de Tomás. Só lhe faltou a libertação da cosmologia cristã para tornar o tema adjacente mundano em ator principal, que por vezes parece bem trabalhado demais para ser apenas coadjuvante (teria Tomás escondido uma política moderna sob uma política teológica medieval?).

\section{Conclusão}

Ao comparar a obra de Tomás com a de Maquiavel os dois resultados mais imediatos são, em primeiro, a percepção óbvia de suas diferenças, e em segundo, uma espantosa semelhança. Nas diferenças se apresentam as mudanças constitutivas da realidade política do ocidente em sua passagem do mundo medieval para o renascimento. O movimento, do qual Tomás é um início e Maquiavel um final, apresentado por COSTA; PATRIOTA (2004 p. 7-8):

Com o esgotamento espiritual da alma da cultura mágico-religiosa, começou a secularização da vida, o espírito de mundanidade penetrou nas relações sociais e os Séculos XIII, XIV, XV e mesmo XVI exibem uma potente mudança cultural. Os fatos políticos e econômicos tomam relevo, em detrimento do religioso e do teológico; o Poder estatal aumenta, gradativamente, a sua interferência e o seu controle nas relações humanas: o Governo se expande e se condensa.

Nas semelhanças, vê-se a continuidade da reflexão política como um jogo de equilíbrio entre a busca do bem comum e a do bem privado, com as diversas implicações que dele derivam.

A primeira diferença absolutamente visível é o lugar de uma cosmologia cristã na construção de modelos políticos. Em Tomás o cristianismo é uma pedra fundamental para entender o procedimento do governante, e se insere como definidor de sua hierarquia dos fins, colocando a missão e recompensa do governante no horizonte da conquista dos bens celestiais. É possível mesmo justificar a submissão à tirania e ao mesmo tempo condenar o tirano dentro da previsão escatológica cristã.

A divisão do poder em espiritual e secular, com sua conclusão cesaropapista e sistematização hierárquica de bens e finalidades do mundano inferior para o celeste superior, gera em Tomás um dualismo estranho ao pensamento maquiavélico.

Este dualismo sustenta a política tomista. É possível entender seu livro em duas partes: a política divina e a política mundana. E só é possível manter o cristianismo como base da política mundana se, e somente se, se admitir a cosmologia cristã como ponto de partida. Na verdade, por ter a política celeste uma posição superior, que assim salva o mundo de uma política mundana, Tomás pode falar, dentro de um contexto cristão, sobre a política mundana como ela é. A política celeste lhe dá um álibi, uma máscara, para refletir sobre o mundano sem o horizonte do desespero e maldade inevitável que Maquiavel enfrenta. A política moderna nasce da retirada do suporte cristão, da teologia moral, para onde as esperanças e medos da filosofia jogavam seus paradoxos em busca de solução divina.

FILHO, José Arlindo de Aguiar. A política no fim da idade média e sua influência no renascimento: entre o "De regno - ad regem cypri", de São Tomás, e "Il principe", de Maquiavel. Griot : Revista de Filosofia, Amargosa - BA, v.19, n.2, p.265-283, junho, 2019. 
Mas Tomás não se furtou a pensar a política mundana. E nela surgem as semelhanças surpreendentes com Maquiavel. Uma leitura maquiavélica de Tomás diria que nesses pontos ele fala o principal, protegido pelo indispensável disfarce cristão da política divina. Independentemente do quão maquiavélico seria Tomás, sua política mundana antecipa em vários pontos o realismo e crueza da leitura moderna do fenômeno político: o rei é movido a glória; a finalidade justifica o meio; o bem comum é promovido ao se estabelecer como meio para o bem privado do governante; o bem comum é a subsistência, o deleite e a segurança; o bem privado do governante são as riquezas e a glória.

"Os homens em geral julgam mais pelos olhos que pelas mãos, porque ver toca a todos, sentir toca a poucos: todos veem aquilo que tu pareces, poucos sentem aquilo que tu és." (MAQUIAVEL, 2017 p. 201). Para entender a política é preciso entender o processo de retirada de suas máscaras. De Tomás a Maquiavel, de Aristóteles à sociedade do espetáculo.

FILHO, José Arlindo de Aguiar. A política no fim da idade média e sua influência no renascimento: entre o "De regno - ad regem cypri", de São Tomás, e "Il principe", de Maquiavel. Griot : Revista de Filosofia, Amargosa - BA, v.19, n.2, p.265-283, junho, 2019. 


\section{Referências:}

AQUINO, São Tomás de. Do reino ou do governo dos príncipes ao Rei de Chipre. In.: Escritos Políticos. Petrópolis: Vozes, 1995.

ARISTOTELES. Politics. In.: The complete works of Aristotle. Edited by Jonathan Barnes. Princeton: Princeton University Press, 1995.

ARISTOTELES. Nicomachean ethics. In.: The complete works of Aristotle. Edited by Jonathan Barnes. Princeton: Princeton University Press, 1995.

BIGNOTTO, Newton. Maquiavel republicano. São Paulo: Loyola, 1991.

COSTA, Marcos Roberto Nunes; PATRIOTA, Raimundo Antônio Marinho. Origens medievais do estado moderno: Contribuições da filosofia política medieval para construção do conceito de soberania popular na modernidade. Recife: INSAF, 2004.

DE BONI, Luís Alberto. Tomás de Aquino entre a urbe e o orbe: o pensamento político de Santo Tomás no De Regno. In.: A ética medieval face aos desafios da contemporaneidade. Porto Alegre: EDIPUCRS, 2004.

LIMA, José Jivaldo. Da política à ética: o itinerário de Santo Tomás de Aquino. Tese de doutorado. Orientação do prof. Dr. Luís Alberto De Boni. Faculdade de Filosofia e Ciências Humanas, Pontifícia Universidade Católica, Rio Grande do Sul. 2005

MAQUIAVEL, Nicolau. O Príncipe. São Paulo: Editora 34, 2017.

MAQUIAVEL, Nicolau. O Prícipe: com notas de Napoleão Bonaparte. São Paulo: Revista dos Tribunais, 2008.

MAQUIAVEL, Nicolau. Comentários sobre a primeira década de Tito Lívio. Brasília: Universidade de Brasília, 1994.

STRAUSS, Leo. Reflexões sobre Maquiavel. São Paulo: É realizações, 2015.

Autor(a) para correspondência: José Arlindo de Aguiar Filho, Universidade Estadual da Paraíba, Rua Baraúnas, 351 - Universitário, 58429-500, Campina Grande - PB, Brasil. arlindoaguiar@bol.com.br

FILHO, José Arlindo de Aguiar. A política no fim da idade média e sua influência no renascimento: entre o "De regno - ad regem cypri", de São Tomás, e "Il principe", de Maquiavel. Griot : Revista de Filosofia, Amargosa - BA, v.19, n.2, p.265-283, junho, 2019. 